\title{
INTRAFAMILIAL HYBRIDIZATION IN MOSSES? AN ENIGMATIC CASE IN THE GENUS PODPERAEA (HYPNALES, BRYOPHYTA)
}

\author{
ГИБРИДИЗАЦИЯ МЕЖДУ ПРЕДСТАВИТЕЛЯМИ РАЗНЫХ \\ СЕМЕЙСТВ У МХОВ? ЗАГАДОЧНЫЙ СЛУЧАЙ \\ В РОДЕ PODPERAEA (HYPNALES, BRYOPHYTA)
}

\author{
MiChAEL S. IGNATOV $^{1} \&$ IRINA A. MiLYUTINA ${ }^{2}$ \\ МИХАИЛ С. ИГНАТОВ ${ }^{1}$, ИРИНА А.МИЛЮТИНА ${ }^{2}$
}

Abstract

A new species from China, Podperaea baii, is described. In addition to morphological differences from the second species of the genus, P. krylovii (Amlystegiaceae s.1.), P. baii differs in the nrITS1 sequence, which is very similar to that of the genus Herzogiella from the phylogenetically distant family Plagiotheciaceae. At the same time, nrITS2 in P. baii is much more similar to Amblystegiaceae than Plagiotheciaceae. This case is the first report of the putative remote hybridization in mosses.

Резюме

Из Китая описан новый вид, Podperaea baii, который, помимо небольших морфологических отличий от второго вида рода, P. krylovii (семейство Amlystegiaceae s.1.), отличается еще последовательностью ITS1, которая соответствует роду Herzogiella из филогетически далекого семейства Plagiotheciaceae. При этом последовательность ITS2 у P. baii значительно более сходна с Amblystegiaceae, нежели c Plagiotheciaceae. Данный случай является первым примером возможной отдаленной гибридазации у мхов.

KEYWORDS: Bryophytes, pleurocarpous mosses, Plagiotheciaceae, Amblystegiaceae, Podperaea, new species, China, remote hybridization, nrITS

\section{INTRODUCTION}

The genus Podperaea was established by Iwatsuki \& Glime (1984) for one species, originally described as Campylium krylovii Podp. The strongly prorate cells and specific 'compound' teeth along leaf margin formed by upper end of lower cell and lower end of next upper cell, were found to be quite odd for Campylium. Similar teeth are rare in Hypnales, and are well developed, as far as we know, only in Myurella and Platydictya.

All other species ever placed in the genus Campylium (except C. krylowii) never have 'compound' teeth. This genus in its traditional circumscription included species that are now treated in many genera: Campylium s. str., Campylophyllum, Campyliadelphus, Campylidium, and in addition some species were transferred to Amblystegium, Drepanocladus and Pseudocampylium (cf. Hedenäs, 1997; Ochyra et al., 2003; Ignatov et al., 2007; Vanderpoorten \& Hedenäs, 2009). None of these genera have sufficient similarity with Podperaea krylovii, and none of them have been found related to it in the molecular analysis of Troitsky et al. (2007), the only study where the position of Podperaea

1 - Main Botanical Garden, Russian Academy of Sciences, Botanicheskaya 4, Moscow 127276 Russia - Россия 127276 Москва, Ботаническая, 4, Гланвый ботанический сад PAH, e-mail: misha_ignatov@list.ru

2 - A.N.Belozersky' Research Institute of Physico-Chemical Biology, Moscow State University, Moscow 119991 Russia - Россия 119991 Москва, МГУ, НИИ Физико-химической биологии им. А.Н. Белозерского, еmail: iramilyutina@yandex.ru 
krylowii has been tested by phylogenetic methods.

The placement of the genus remains problematic, which is a common case at the moment for many genera of pleurocarpous mosses. Originally it was referred to Hypnaceae that was a repository for pleurocarps with double costa and complete double alternate peristome and without specific characters that would indicate an affinity to families like Neckeraceae, Sematophyllaceae, Hylocomiaceae, etc. However, the type species of the family Hypnaceae, Hypnum cupressiforme, is obviously quite unrelated to Podperaea (Troitsky et al., 2007).

Podperaea krylovii was described from the Russian Far East and later found in a number of places in South Siberia, and in Hokkaido, Japan (Iwatsuki \& Glime, 1984), in Liaoning Province of China (Ignatov et al., 1996) and then also in Inner Mongolia Autonomous District of China (Zhao et al., 2006; Bai, 2010).

Collections from different parts of Russia studied by us have been fairly homogeneous morphologically, so posed no questions about their species identity. The variation seen in Chinese specimens however was bigger: specimens from Khingan Mts. (ranging from Amurskaya Province of Russia and Heilongkiang Province of China to Inner Mongolia) were found nearly identical to Russian ones, whereas plants from another region, Inner Mongolia, appeared to be different in morphology, so the testing with molecular markers was applied to these specimens.

An unexpected preliminary results have forced us to search additional collections from Inner Mongolia, and new gatherings have confirmed the preliminary observation that the most widespread population in the Inner Mongolia is an undescribed species, Podperaea baii (see description below).

\section{MATERIAL AND METHODS}

The taxa selection for phylogenetic analysis was done with the focus on genera possibly related to Podperaea according to the results of Troitsky et al. (2007). The subset of taxa used in the previous analyses (Ignatov et al., 2007; Troitsky et al., 2007) was taken. New and already published sequence data used in analysis are given in Appendix 1.
Laboratory protocol was essentially the same as in some of our previous analyses (e.g., Gardiner et al., 2005). The sequences were aligned manually in Bioedit (Hall, 1999). Maximum parsimony analysis and jackknifing for 1000 replications was performed in Nona (Goloboff, 1994) under Winclada shell (Nixon, 1999).

In the present paper only ITS data are analyzed, as this DNA region is the most variable in mosses, and the results of its sequence analyses often correspond to genera and families of many pleurocarpous moss groups in their traditional circumscriptions. Preliminary tests with chrloroplast markers $\operatorname{trn} \mathrm{L}-\mathrm{F}$ and $r p s 4$ have given poor resolution and are not presented here.

As the prelimirnary study revealed a considerable difference between systematic position that follows from a separate analysis of ITS1 and ITS2, these loci were studied separately. Hereafter within this paper we will call them ITS1 and ITS2 for simplicity, although the former locus includes ITS1, 5.8 RNA gene and a short part of 3'end of ITS2 (38 positions in the alignment (30-37 nucleotides for different species, up to 678 position of the alignment), while ITS2 in a slightly reduced part of this spacer, representing 503 positions closer to 5 '-end, i.e. without 38 mentioned positions of the alignment from the 3'-end.

\section{RESULTS}

The MP tree based on the ITS1-2 region and rooted on Hookeria (Fig. 1) includes basal polytomy of the species classified in Plagiotheciaceae (sensu Pedersen \& Hedenäs, 2002; Ignatov et al., 2007, etc.) and also Fabroniaceae and Stereophyllaceae and terminal clade.

Within the basal polytomy, a high jackknife support was obtained for clades formed by species of one genus, e.g., Herzogiella (93), Struckia (99), and also Plagiothecium + Struckia clade was supported (95), as well as Fabroniaceae+ Stereophyllaceae (90).

Terminal clade includes two subclades. The first small subclade is formed by 5 accessions of Podperaea baii (jackknife support 100). The second larger subclade (support 97) represents a poorly resolved terminal polytomy of various groups of Hypnales. Within this polytomy, a high support has been received by many families (usually represented by few specimens), e.g., Hyp- 


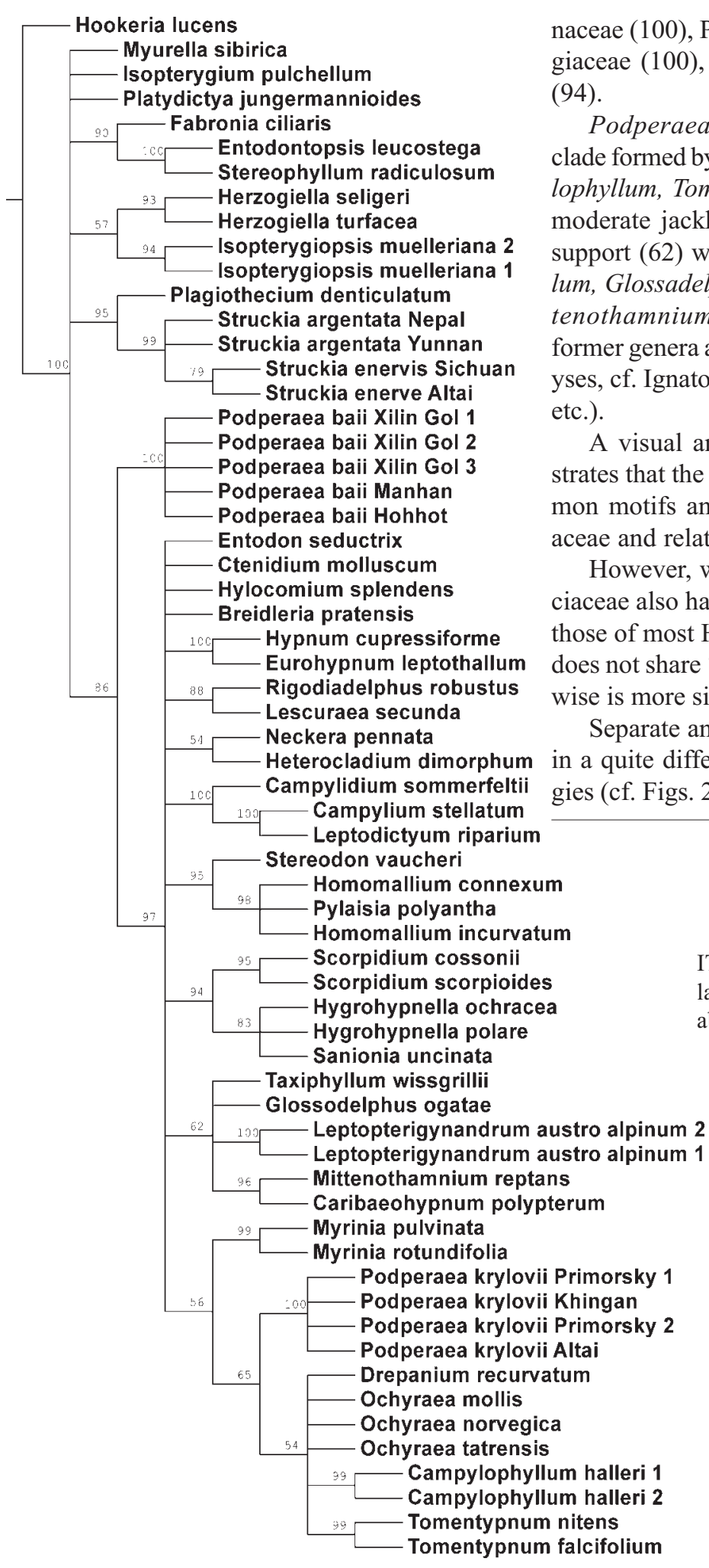

Fig. 1. Jackknife tree based on ITS $1-2$ dataset; supports $>50 \%$ calculated for 1000 replications are shown above branches. 


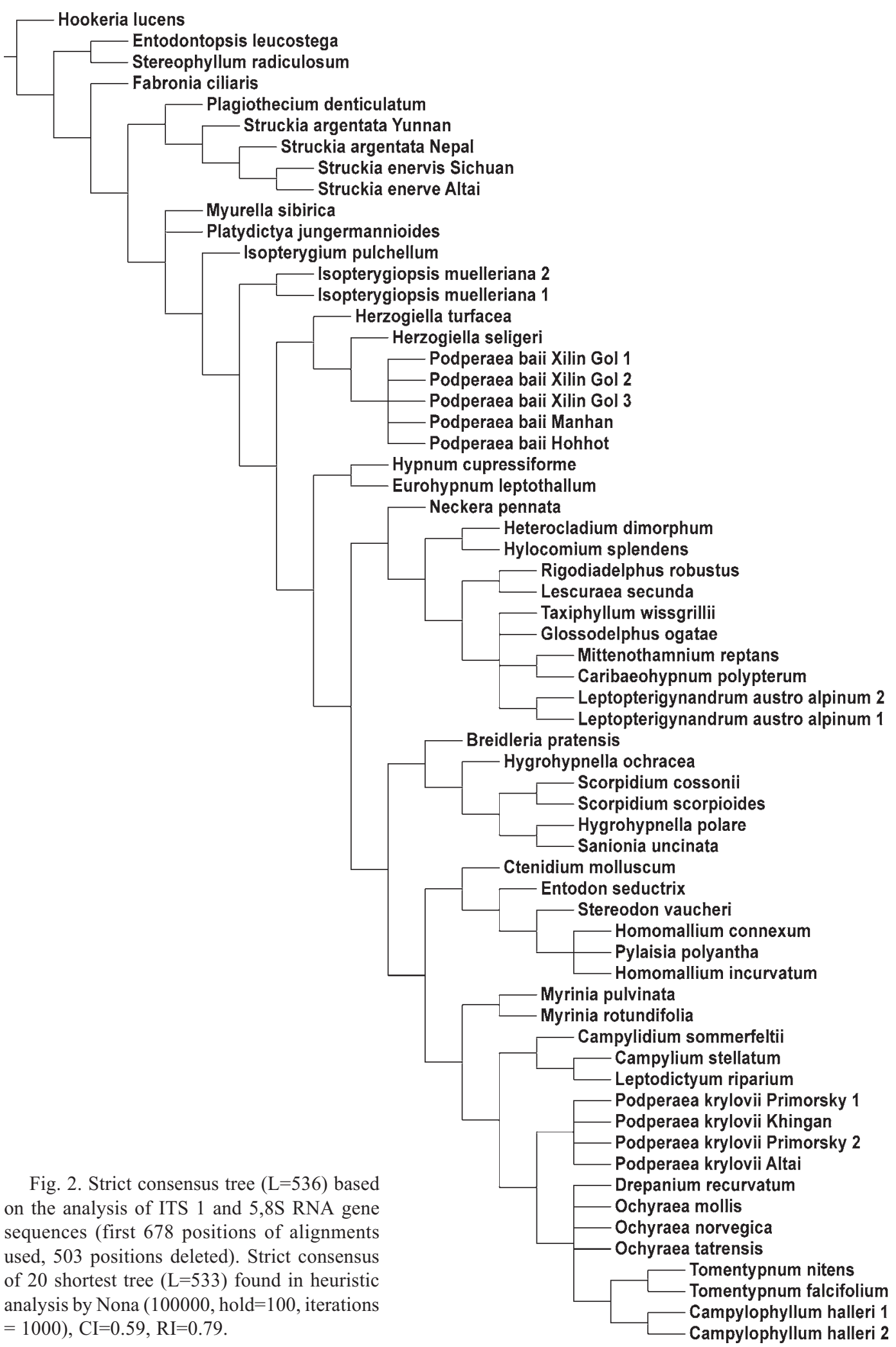


Hookeria lucens

Myurella sibirica

Isopterygium pulchellum

Platydictya jungermannioides

Isopterygiopsis muelleriana 2

Isopterygiopsis muelleriana 1

\begin{tabular}{|l}
\hline Herzogiella seligeri \\
\hline Herzogiella turfacea
\end{tabular}

Fabronia ciliaris
Entodontops is leucostega

Stereophyllum radiculosum

Plagiothecium denticulatum

Struckia enervis Sichuan

Struckia enerve Altai

Struckia argentata Nepal

Struckia argentata Yunnan

Rigodiadelphus robustus

Lescuraea secunda

Hypnum cupressiforme

Eurohypnum leptothallum

Hygrohypnella ochracea

Hygrohypnella polare

Sanionia uncinata

Scorpidium cossonii

Scorpidium scorpioides

\begin{tabular}{|l} 
Neckera pennata \\
Heterocladium dimorphum \\
Entodon seductrix
\end{tabular}

Entodon seductrix

Hylocomium splendens

Campylidium sommerfeltii

Campylium stellatum

Stereodon vaucheri

- Homomallium connexum

Pylaisia polyantha

Homomallium incurvatum

Breidleria pratensis
Mittenothamnium reptans

Caribaeohypnum polypterum

Taxiphyllum wissgrillii

Glossodelphus ogatae

Leptopterigynandrum austro alpinum 2

Leptopterigynandrum austro alpinum 1

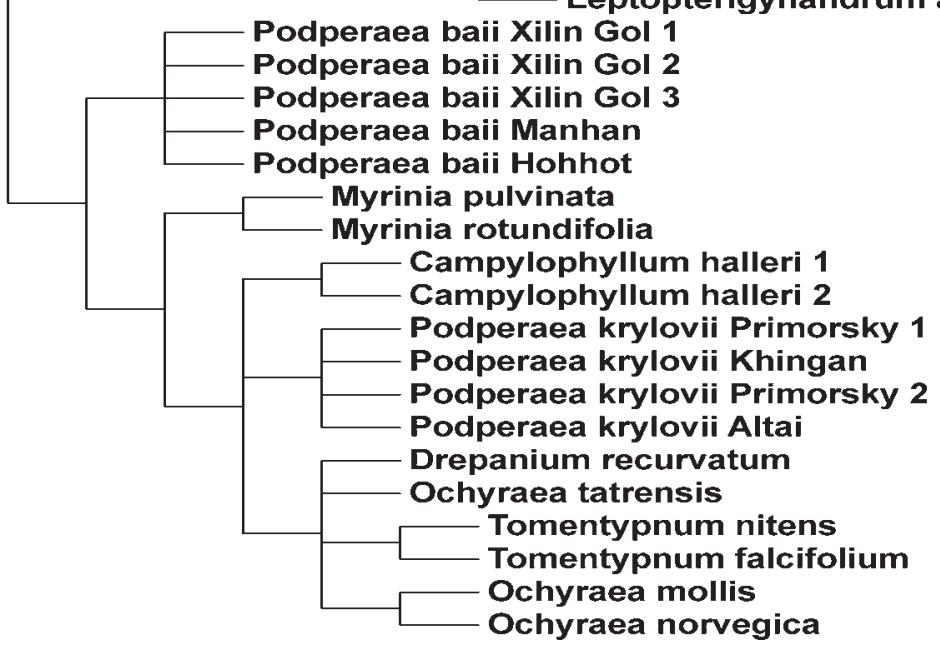


HONOMALLI UM CONEXUM HOMOMALLI UM I NCURVATUM PYLA SI A_ POEYANTHA STEREODON VAUCFER HYPNUM CUPRESSI FORME EUROMYPNUM LEPTOTHALLUM BREI DLERI A PRATENSI S CTEN DI UM MOLUSCUM NECKERA PENNATA HYLOCOM UM SPLENDENS ENTODON SEDUCTRI $X$ M TTENOTHHAMN UM REPTANS HYGROHYPNELLA ОCHRACEA HYGROHYNELLA- POLARE SAN ON A UNCI NATA SCORPI DI UM COSSON I SCORPI DI UM SCORPI O DES CARI BAEOHYPNUM POLYPTERUM HETEROCLAD UM D MORPHUM LESCURAEA_SECŪNDA RI GODI ADELPHUS ROBUSTUS TAXI PHMLLUM W S̄SGRI LLII LEPTOPTERI GYNANDRUM A ALPI NUNR LEPTOPTERI GINANDRUM A ALPI NUM GLOSSODELPHUS OGATAE DREPAN UM RECURVATUM OCHYRAEA MOLLIS

OCHYRAEA- NORVEG CA OCHYRAEA TATRENSI S CAMPYLOPHMLLUM HALLER 1 CAMPYLOPHMLLUM HALLERI_2 MRI N A PULV NATA MRI N A ROTUND FOL A CAMPYLI UM STELLATUM LEPTODI CTYYM RI PARI UM CAMPYLI DI UM SOMERFELTI I TOMENTYPNUM N N TENS TOMENTYPNUM FALC FOLI UM PODPERAEA_KRYLOM I_PRI MORSKY1 PODPERAEA- KRYLOM I-KH NGAN POOPERAEA- KRYLOM I-PRI MORSKY2 PODPERAEA KRYLOM I ALTAI

$\Gamma$ POOPERAEA_BA I_X LIN_GOLI PODPERAEA BAI I XI LI N GQ2 POOPERAEA BA I_XI LI N GQ.3 PODPERAEA BA I MANHAN PODPERAEA BA I HOHOT PLAG OTHĒ UM DENTI CULATUM STRUCK A ENERM S_SI CHUAN STRUCK A ARGENTATA NEPAL MURELLA_SI BI RI CA IERZOG ELLA SELI GERI IERZOG ELLA TURFACEA STRUCK A_ARGENTATA YUNNAN STRUCW A ENERVE ALTA I SOPTERYG OPSI S MUELLERI ANA2 I SOPTERYG OPSI S MELLERI ANAI I SOPTERYG UM PÜCHELLUM

L PLATYDI CTYA J UNCERMAN O DES ENTODONTOPSTS LEUCOSTEGA FABRON A C LI ARI S HOOKERI A- LUCENS

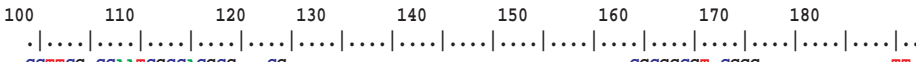
CCTTCG CCAATCGCCACGCG - CG ........ CGCGGCG CGGG $\ldots$ CCTICG CCAATCGCCACGCG - CG . . . . . . . . . . . . . . . . CCTTCG CCAATCGCCACGCG - CG .......... CGCGGCG - CGGG CCTTCG C CACGCG CG - CGCGCCG - CGGG

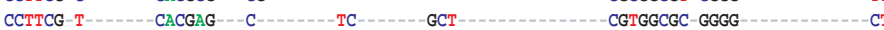

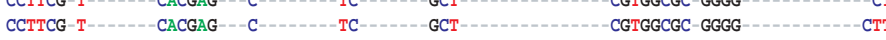

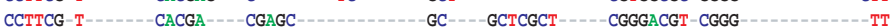

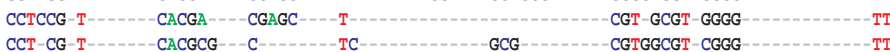

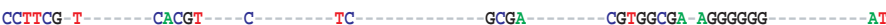
CCTCG T . . CACGAG CGAGC - TC . . . . GCTCGT . CGCGGCG GGGG .

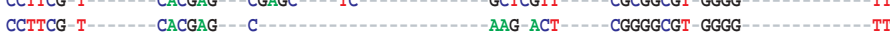

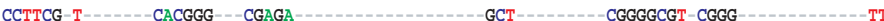
CCTTCG T . CACGAG CGAGA . . . . CGT . . . CGCGCGT CGGG . . . . . . TT

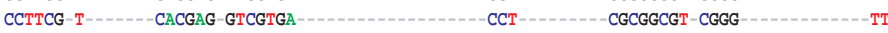
CCTTCG T . CACGAG . CGAGA . . CGGGCG - CGGG . CCTTCG T- . CACGAG CGAGA

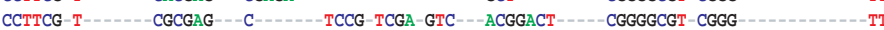

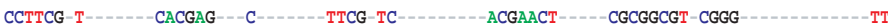
CCTTCG T- CACGAG C C... T- CGTGGCG CGGG

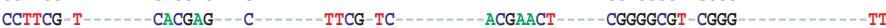
CCTTCG T . . . CACGAG - C . . . TTCG TC ACGTC . ACGAACT . . . CGGGGCG CGGG . . . . . . . . TT

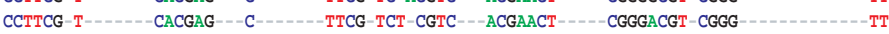
CCTTCG T . . . . CGCGAG . C . ..... TTCG TCC CGTC . ACGAACT . . . CGGGCG CGGG CCTTG T . . CACGAG C . . TTCG TC ACGT - ACGAACT . . CGGGGCG CGGG . . . . . . . TI CCTTCG T . .... CACGAG - CGAGC ... TCCCTC - GCGA - GCTCCCT .... CGCGGCG CGGG ......... TT CCTTCG T . . . CACGAG - CGACC - TCCCTC - GCGA - GCTCCCT . . CGCGGCG - CGGG . . . . . . . TT CCTTCG T . CACGAG - CGAGC - TCCCTC GCGA - GCTCCCT . . CGCGGCG CGGG . . . . . . . TT

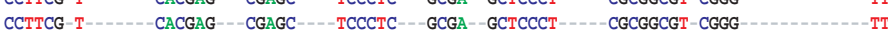
CCTTCG T . CACGAG - CGACC . TC . . GCGA - GCTCTCT . CGCGGCG CGGG . . . . . . TT CCTTCG T- . CACGAG CGAGC - TC . . GCGA GCTCTCT . . CGCGGCG CGGG .......

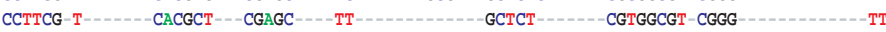
CCTTCG T . . . CACGCT - CGACC . . TC . . . . GCTCT . . . CGTGGCG CGGG . . . . . . TT CCTTCG T- CACGCG CGAGCGAGITC CTC GGG GCTCCCTCGCGGCGCGGCG- CGGG - G CCTTCA T- . . . CACG G - AGAGCGAGITC CTC - . TGG - GCTCCCTCGCGGCGCGGCG - CG G . . . . . . . . T CCCTCG T- . CACGCG - CGAGCGAG TCCCTC - GTG - GCTCCCTCGCGGCGCGCCG - CGGG . . . . . . . T CCTTCG T- CACGAG CGAGCGACTC- TC GCGA GCTCTCT .... CGCGGCG CGGG ....... CCTTCG T . . CACGAG - CGAGCGAGCTC - TC GCGA - GCTCTCT . . CGCGGCG CGG . . . . . . . . TI CCTTCGG - . CGCGCG - CGAGCCCGCTC . . GCGG GCTCCCT . . CGCGGCG CGGG . . . . . . . . CYTTCG T . CACGCG CGAGCCCGCTC . . GCGG GCTCCCT . . CGCGGCG CGGG

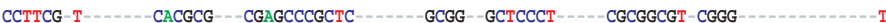

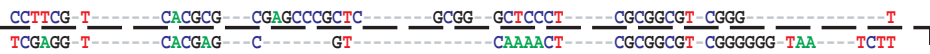
TCGAGG T . . . CACGAG - C . . . . GT . . CAAACT . . . CGCGGCG CGGGGG TAA . . TCTT TCGAG T . . . CACGAG C C . . . GT . . . . CAAACT . . . CGCGGCG CGGGGG TAA . . TCTT TCGAG T . CACGAG C C . . . GT . . . CAAAACT . . CGCGGCG - CGGGGG TAA . . TCTT TCGAG T . . . CACGAG C C . . . GT . . . . CAAACT . . CGCGGCG CGGGGGG TAA . . TCTT

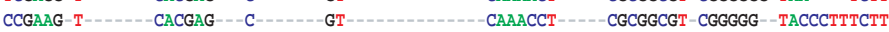
CCGATG T . . . CTCGAG C C . . GT . . CCAAACT . . CGGGCG - CGGGG - TAC . . TCT CCGAG T . . . CTCGAG - C . . . . GT . . . . . CAAACT . . CGGGGCG CGGGGG TAC . . . TC CCGAGG T . CACGAG C . C. GT . . . . CAAACT . CGGGG CGGGGG TAA ... TIT TCGAG C . . . CCCGAG . C . . . . GT . . . . . CAAACT . . CGGGCGT- CGGGGG TAA . . TCT TCGAG T . . . . CACGAG . C . . . . GT . . . . . . CCAAACT . . CGGGGCG CGGGGG TAA . . TCT

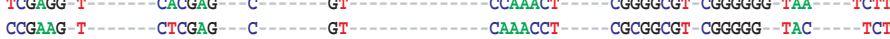
CCGATG T . .... CTCGAG - C . . . . GT . . . CCAAACT . . . CGGGCGT CGGGGG - TAC .... TCT CCGAGG T . . . . CACGAG . C . . . . GT . . . . . CGCAACT . . . CGTGGCG CGGGGGG TAC . . TCTT

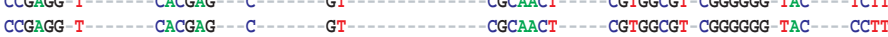
CCGIT T . . . CACGAG . C . . . GT . CCAACT . . CGTGGCG CGGGGG TAA . . TCTT CCGAGG T . CACGAG C C CAAACT CGGGCG CGGGGG TAA - . TCT

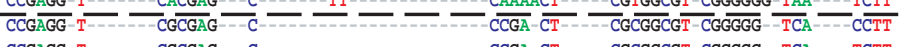
CCG IGG T . . . CGCGAG . C . . . . CCGA CT . . CGCGCGT- CGGGG - TCA . . TCT CCGAGA C CGCGAG C C...TT CACGGCG CGGGG TAA - TCTT CCGAGG T . . . CACGAGA - C . . . TT . . . . CCC GCT . . CGCGGCTTCCGGGGGA AAA . . TC

Fig. 4. Part of ITS 1 alignment, showing common substitutions and indels of Podperaea baii and Plagiotheciaceae.

ITS1, resolved Podperaea baii as sister to Herzogiella within the basal grade.

At the same time, strict consensus for ITS2 sequences has found both Podperaea krylovii and P. baii in one clade, which also includes Myrinia and four genera, Ochyraea, 'Drepanium', Campylophyllum, Tomentypnum, the same as have been found in the combined analysis of ITS1 and ITS2.
Visual evaluation of sequences demonstrates at once that ITS1 region in Podperaea baii has all characteristic motifs of Plagiotheciaceae, which are numerous and readily seen (Fig. 4).

ITS2 in pleurocarpous mosses is less variable compared with ITS1 and rather few characteristic places in the alignment are revealing. Most of them demonstrate the difference between 
HOMOMELLI UM CONEXUM

PYLA SI A PQ̄YANTHA

HOMOMALI UMI I NCURVATUM

STERECDON VAUCFERI

TAXI PHMLLUM W SSGRI LLII

LEPTOPTERI GYNANDRUM A ALPI NUMR

LEPTOPTERI GINANDRUM A ALPI NUM

GLOSSODELPHUS_OGATAE

ENTODON SEDUCTRI $X$

M TTENOTHAMN UM REPTANS

CARI BAEOHPNUM POYYPTERUM

HYPNUM CUPRESSII FORNE

EUROFYPNUM LEPTOTHALLUM

CTEN DI UM MOLUSCUM

NECKERA PENMATA

IETEROCLADI UM DI MORPHUM

HMOCOM UM SPLENDENS

BREI DLERI A- PRATENSI S

CAMPYLOPHYLLUM HALLERI 1

CAMPYLOPHMLLUM HALLERI_2

DREPAN UM RECURVATUM

CAMPYLI UM STELLATUM

LEPTODI CTYUM RI PARI UM

HYGROHYPNELLĀ OCFRACEA

HYGROHYNELLA- POLARE

RI GODI ADELPHŪS_ROBUSTUS

SAN ON A UNC NATA

SCORPI DI UM COSSON I

SCORPI D UM SCORPI O DES

CAMPYLI D UM SOMERFELTII

LESCURAEA_SECUNDA

OCHYRAEA MOLLIS

OCHYRAEA NORVEG CA

OCHYRAEA TATRENSI S

TOMENTYPNUM N TENS

TOMENTYPNUM FAL G FQII UM

MRI N A_PUV̄ NATA

MRI N A ROTUDD FOLIA

PODPERAEA KRYLOM I_PRI MORSKY_1

PODPERAEA_KRYLOM I_KH NGAN

PODPERAEA KRYLOM I_PRI MORSKY 2

POOPERAEA_KRYLOM I_ALTA

PODPERAEA_BA I HELĀN I

PODPERAEA BAI I HELAN 2

PODPERAEA_BA I_HELAN_3

PODPERAEA- BA I_MANHAN

PODPERAEA BAII HOHOT

PिLAG OTHECI UM DENTI CULATUM

STRUCK A ENERV S_SI CHUAN

STRUCK A- ARGENTATA_ NEPAL

IMURELLA-SI BI RI CA

IERZOG ELLA SELI GERI

IERZOG ELLA- TURFACEA

STRUCK A ARGENTATA YUNAN

STRUCK A ENERVE ALTA

I I SOPTERYG OPSI S_MUELLERI ANA 2

I SOPTERYG OPSI S MELLERI ANA-1

I SOPTERYG UM PÜLCELLUM

LPLATYD CTYA J UNGERMAN Q DES

ENTOOONTOPSI S_LEUCOSTEGA

STEREOPHYLLUM RADI CULOSUM

FABRON A_ C LI ARI S

HOOKERI A LUCENS

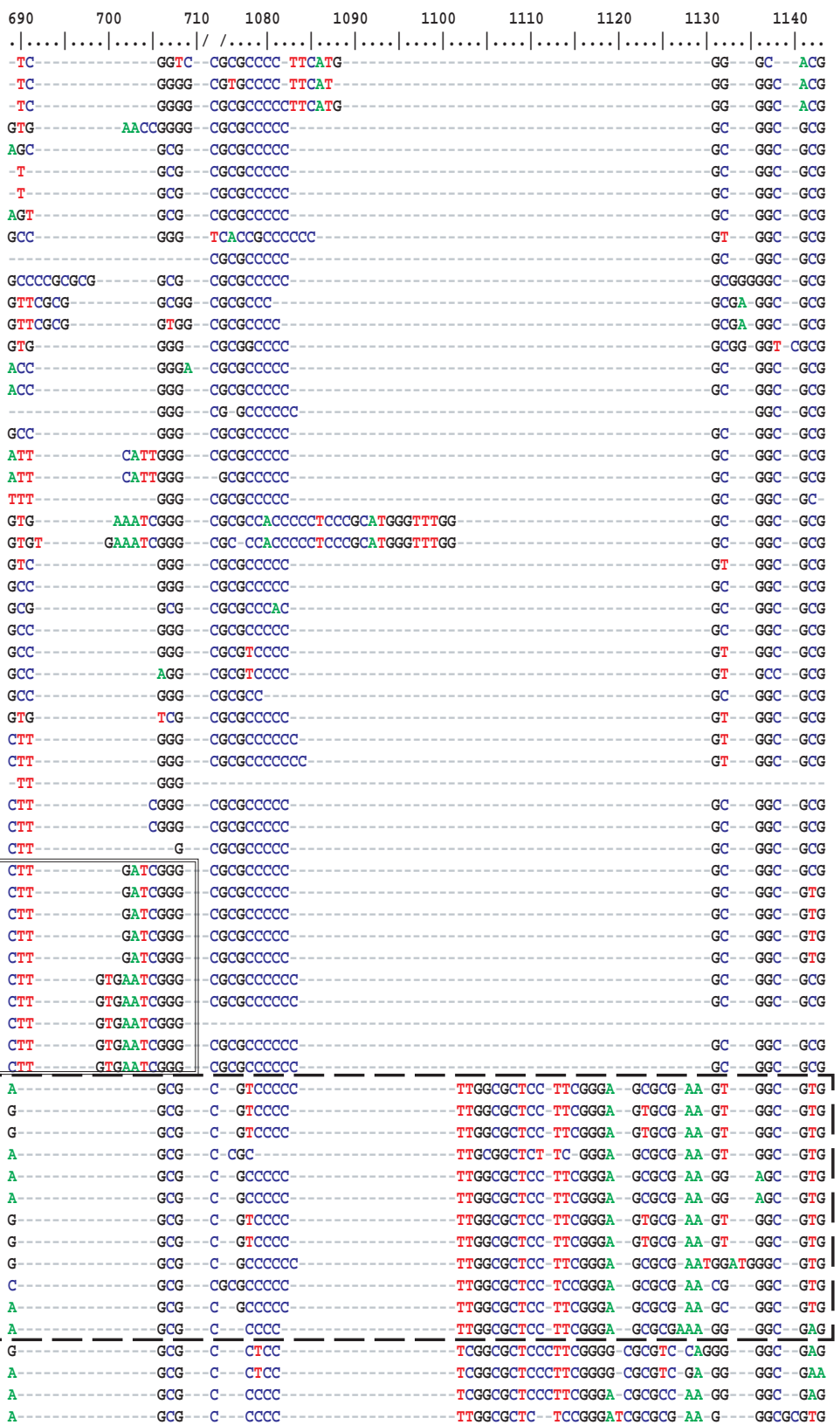

Fig. 5. Part of ITS 2 alignment, showing absence of common substitutions and indels of Podperaea baii and Plagiotheciaceae.

Plagiotheciaceae + Stereophyllaceae + Fabroniaceae + Hookeriaceae and the rest of group represented in the analysis. However none of them indicate the relationship of $P$. baii with Plagiotheciaceae, but instead show that it belongs to that subclade of the termnial polytomy in Fig. 1 where Podperaea krylovii, Campylophyllum, Ochyraea, Myrinia and Tomentypnum occur.
When the first sequence of $P$. baii was analyzed, the possible contamination was suspected. Thus the DNA was cloned and re-sequenced and also re-extracted from sporophyte tissue of the same collection. An additional collections from Inner Mongolia were also looked for, including a special field trip in 2011, and two of new collections of $P$. baii, from geographically different 


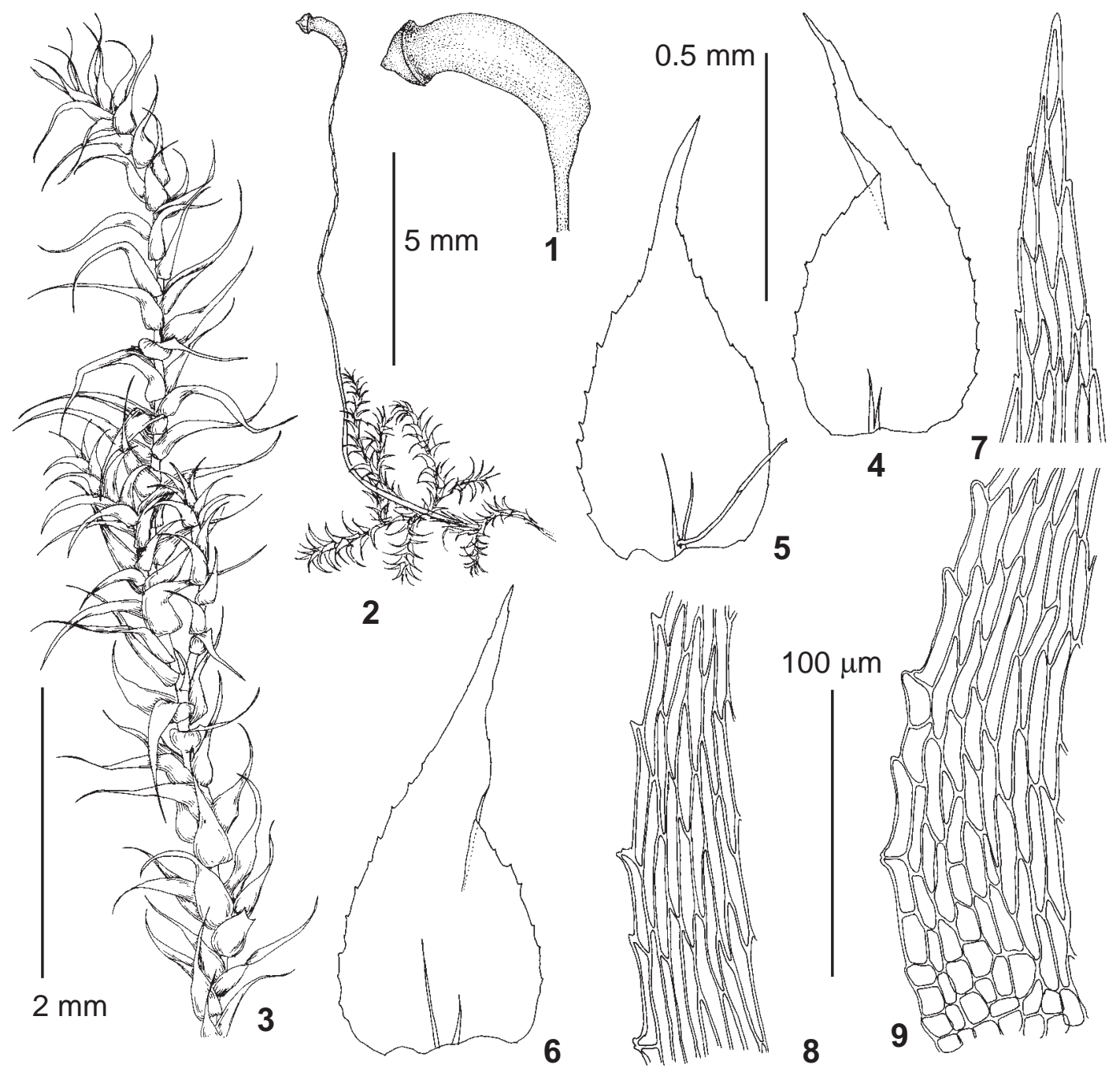

Fig. 6. Podperaea baii (Hedw.) Müll. Hal. (from isotype: China, Inner Mongolia, Xilin Gol, Bai X.-L. 058141, MHA): 1 - capsule; 2-3 - habit; 4-6 - leaves; 7 - upper laminal cells; 8 - mid-leaf cells; 9 - basal laminal cells. Scale bars: $5 \mathrm{~mm}$ for $2 ; 2 \mathrm{~mm}$ for 1,$3 ; 0.5 \mathrm{~mm}$ for $4-6 ; 100 \mu \mathrm{m}$ for 7-9.

areas within Inner Mongolia Autonomous District of China have given the same ITS sequence: "plagiothecioid" ITS1 and "non-plagiothecioid" ITS2.

\section{DISCUSSION}

The ITS and especieally ITS1 of Plagiotheciaceae-Stereophyllaceae-Fabroniaceae group has many specific motifs (Fig. 4), also shared with Hookeriaceae. The mentioned families are characterized by expanded insertions, as well as substitutions in a fairly conservative places (Fig. 4).

Peculiar motifs of Plagiotheciaceae in ITS2 are not so many, but nevertheless some expanded indels differ this family (and some above mentioned related families) from the rest of Hypnales (Fig. 5). However none of them are found in P. baii, in contrast with ITS1 were the 'plagiothecioid specificity' is totally shared by P. baii.

ITS2 of $P$. baii differs somewhat also from $P$. krylovii, although strict consensus tree in the maximum parsimony analysis resolves them within one clade, together with marginal groups of Amblystegiaceae (Camylophyllum, Tomentypnum, Drepanium, and Myrinia). 

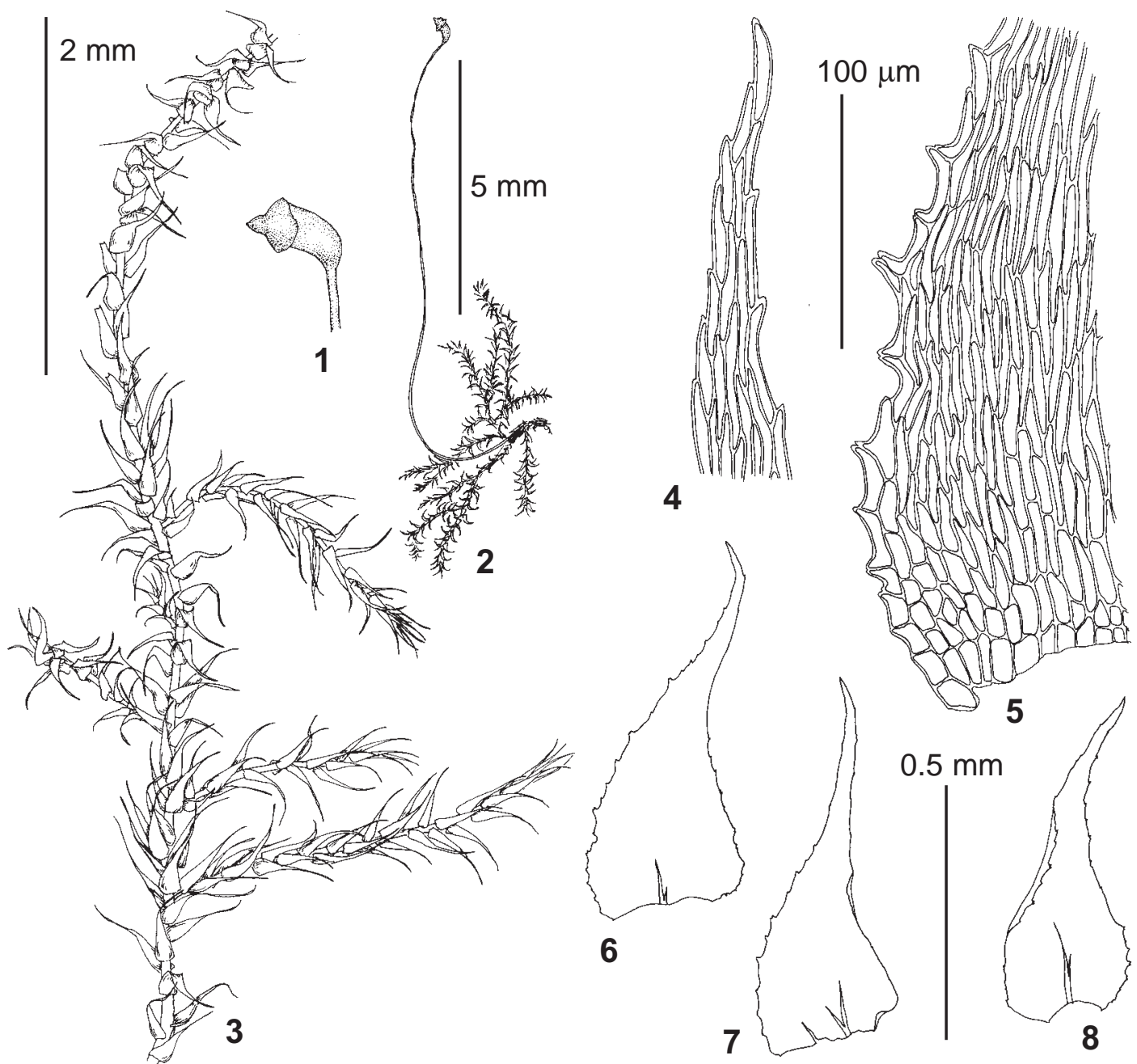

Fig. 7. Podperaea krylovii (Podp.) Müll. Hal. (from China, Inner Mongolia, Khingan Mts., Bai X.-L. 04095, MHA): 1 - capsule; 2-3 - habit; 4 - upper laminal cells; 5 - mid-leaf and basal laminal cells; 6-8 - leaves. Scale bars: $5 \mathrm{~mm}$ for $2 ; 2 \mathrm{~mm}$ for 1,$3 ; 0.5 \mathrm{~mm}$ for $6-8 ; 100 \mu \mathrm{m}$ for $4-5$.

Morphological differences between Plagiotheciaceae and 'Hypnales without Plagiotheciaceae and related families' include a number of characters and many of them are highly diagnostic. However, the genus Herzogiella does not belong to the 'core Plagiotheciaceae', so the most unique characters of the family, e.g., axillary position of rhizoides, 'lack of pseudopraphyllia' (cf. Ignatov \& Hedenäs, 2007), axillary 3-4-celled gemmae, and lack of regular pinnate branching are not the case of this genus. Other characters, like pale peristome and a tendency to a complanate branching being common in Plagiotheciaceae, are known in a many other pleurocarpous groups. Molecular phylogenetic studies however always resolved Herzogiella in Plagiotheciaceae, excepting a likely misplaced in the genus $H$. adscendens (Lindb.) Z. Iwats. \& W.B. Schofield.

Although the morphological circumscription of Herzogiella is rather indefinite, this genus is distinct from Podperaea in having only simple marginal teeth, while teeth in the latter are 'compound'. The presence of such teeth in Podperaea baii is the main reason for its placement in this genus.

Podperaea baii Ignatov sp. nov.

A Podperaea krylovii plantis robusioribus, foliis longioribus et latioribus, cellulis latoiribus, glabris, sporiis magnis, et ITS sequentia valde differt. 
Holotype: China, Inner Mongolia (NE, desert area), Xilin Gol, Hun shan de ka, 21.VIII.2005, coll. Bai X.-L. \# 058141(holotype MHA, isotype HIMC).

Ethymology: the species is named in honor of Prof. Bai Xue-liang, an eminent bryologist, who published moss flora of Inner Mongolia in China and collected this moss species.

Plants small, in loose, light green mats. Stem prostrate, to $1 \mathrm{~cm}$ long, with weak central strand, without hyalodermis, irregularly to rather regularly pinnately branched. Proximal branch leaves lanceolate to ovate, sitting around branch primordia on stem. Leaves ovate-lanceolate, gradually more or less longly acuminate, $0.7-0.95 \times 0.35$ $0.45 \mathrm{~mm}$, serrate all around by simple and partly 'compound' teeth; 'compound' teeth rather perpendicular to leaf margin, and more or less acute; costa double or forked, short and weak, or sometimes one of branches of forked costa extends to 0.5 the leaf length; laminal cells 30$70 \times 6-7 \mu \mathrm{m}$; basal cells quadrate to short rectangular, 7-11 $\mu \mathrm{m}$ wide, forming small indistinctly delimited group. Autoicous. Perichaetial leaves somewhat larger than stem leaves, with single costa reaching up half-leaf, serrulate, smooth. Setae to $15 \mathrm{~mm}$. Capsules ca. $1.3 \mathrm{~mm}$ long, arcuate and strongly contracted below the mouth when dry; operculum conic; annulus separated by fragments; peristome double, complete, with long cilia. Spores 17-18 $\mu \mathrm{m}$.

Specimens examined: CHINA, INNER MONGOLIA: Xilin Gol, Bai X.-L. \#058141 (HIMC, MHA); Manhan Shan, Ignatov \#11-1 (MHA); Hohhot, Kou Jin \#110(7) (HIMC, MHA).

We did not see specimens from Helan Shan, alt. $1900 \mathrm{~m}, \mathrm{HQ} 269$, but according to illustrations in Bai (2010) and Zhao et al. (2006) it .

Distinction. Podperaea baii is a somewhat larger plant than P. krylovii, it has broader laminal cells without prorate upper angles; 'compound teeth' are 'more acute' as cells forming a tooth join each other up to the tooth apex, whereas in P. krylovii cells forming a tooth are more or less divergent distally, at least at short distance (cf. Figs. $6 \& 7$ ). In addition, spores in $P$. baii are larger than in P. krylovii, 17-18 $\mu \mathrm{m}$ versus $10-$ $12 \mu \mathrm{m}$.

* $\quad * \quad *$
Remote hybridization is well-known in flowering plants, where widespread artificial and occasionally natural intrageneric hybrids are known $($ Triticum $\times$ Secale $=$ Triticale; Hordem $\times$ Elymus $=$ Hordelymus; Sorbus $\times$ Cotoneaster $=$ Sorbocotoneaster, etc.). These and similar cases however include different genera that belong to the same subfamily, and thus represent a hybridization of only a moderately divergent groups.

Much more remote hybridization is known in orchids, where two or more not very closely related genera may produce stable hybrids: Cattleya $\times$ Laelia $=$ Laeliocattleya; Cattleya $\times$ Sophronitis = Sophrocattleya; Cattleya $\times$ Laelia $\times$ Sophronitis $=$ Sophrolaeliocattleya; Cochlioda $\times$ Miltonia $\times$ Odontoglossum $=$ Vuylstekeara.

In mosses, intrageneric hybrids were found or produced artificially for Funaria $\times$ Physcomitium, Physcomitrium $\times$ Physcomitrella, Weissia $\times$ Astomum (the latter genus is often treated within Weissia), Ditrichum $\times$ Pleuridium (see review of Anderson, 1980). Some Physcomitrium $\times$ Physcomitrella hybrids produce tetrads with 2 of 4 spores viable. According to Wettstein (1924) they have only maternal chromosomes, thus not further reproducing hybrid organisms.

Some of the recent phylogenetic studies, with construction of haplotype network by two independent markers illustrate the possible hybridization in the genus Sciuro-hypnum (Draper \& Hedenäs, 2009).

The case of Podperaea baii likely represents a rare event. ITS is the most variable of DNA regions which are widely used in moss phylogenetics, but not that variable to be useless for phylogeny reconstruction. The large trees that were based on, among others, ITS data, provided many helpful results on the relationships of pleurcarpous mosses (Gardiner et al., 2005; Ignatov et al., 2007; Huttunen et al., 2012).

However the case of Podperaea baii might be important for understanding of a strong incongruence between topology of molecular trees and morphology, like for example, the case of Pinnatella homaliadelphoides Enroth, S. Olsson, S. He, Shevock \& D. Quandt (Enroth et al., 2009). 


\section{ACKNOWLEDGEMENTS}

We are grateful to Profs. Bai X.-L. and Zhao D.-P. for arranging a field trip in China, to E. Ignatova for preparing illustrations of the species. The work was partly supported by RFBR 10-04-91150 and 10-04-00678.

\section{Literature Cited}

ANDERSON, L.E. 1980. Cytology and reproductive biology of mosses. - In: R.J. Taylor \& A.E. Leviton (eds.) The mosses of North America. San Francisco. Pacific Div. Am. Assoc. Adv. Sci. 37-76.

BAI, X-L. 2010. Bryoflora Helanshanica. Typis Ningxia Popularis. Yinchuan. $281 \mathrm{pp}$. [In Chinese].

DRAPER, I. \& L. HEDENÄS 2009. Circumscription of European taxa within the Sciuro-hypnum reflexum complex (Brachytheciaceae, Bryophyta), based on molecular and morphological data. - Taxon 58: 572-584.

ENROTH J., S. OLSSON, S. HE, J.R. SHEVOCK \& D. QUANDT 2010. When morphology and molecules tell us different stories, part 2: Pinnatella homaliadelphoides (Neckeraceae), a new moss species from China and India. - Tropical Bryology 31: 67-75.

GARDINER, A., M. IGNATOV, S. HUTTUNEN \& A. TROITSKY 2005. On resurrection of the families Pseudoleskeaceae Schimp. and Pylaisiaceae Schimp. (Musci, Hypnales). - Taxon 54: 651-663.

GOLOBOFF, P. A. 1994. NONA: A Tree Searching Program. Program and documentation. Argentina, Tucumán, published by the author.

HALL, T. A. 1999. BioEdit: a user-friendly biological sequence aligment editor and analysis program for Windows 95/98/ NT. - Nucl. Acids. Symp. 41: 95-98.

HEDENÄS, L. 1997. A partial revision of Campylium (Musci). - Bryologist 100: 65-88.

HUTTUNEN, S., N. BELL, V.K. BOBROVA, V. BUCHBENDER, W.R. BUCK, C.J. COX, B. GOFFINET, L. HEDENÄS, B.-C. HO, M.S. IGNATOV, O. KUZNETSOVA, I.A. MILYUTINA, A.NEWTON, S. OLSSON, L. POKORNY, J.A. SHAW, M. STECH, A. TROITSKY, A. VANDERPOORTEN, D. QUANDT [2012]. Disentangling knots of rapid evolution: origin and diversification of the moss order Hypnales. - J. Bryol. (submitted).
IGNATOV, M.S., H. ANDO \& E.A. IGNATOVA 1996. Bryophyte flora of Altai Mountains. VII. Hypnaceae and related pleurocarps with bi- or ecostate leaves. - Arctoa 6: 21-112.

IGNATOV, M. \& L. HEDENÄS 2007. Homologies of stem structures in pleurocarpous mosses, especially of pseudoparaphyllia and similar structures. - In: Newton, A.E. \& R. Tangney (eds.), Pleurocarpous mosses: systematics and evolution. CRC Press, Boca Raton-London-New York: 269-286.

IGNATOV, M., A. GARDINER, V. BOBROVA, I. MILYUTINA, S. HUTTUNEN \& A. TROITSKY 2007. On relationships of mosses of the order Hypnales, with the special reference to taxa traditionally classified in Leskeaceae. - In: Newton, A.E. \& R. Tangney (eds.), Pleurocarpous mosses: systematics and evolution. CRC Press, Boca Raton-LondonNew York: 177-213.

IWATSUKI, Z. \& J.M. GLIME 1984. Podperaea, a new genus of Hypnaceae). - J. Hattori Bot. Lab. 55: 495-500.

NIXON, K.C. 1999. Winclada (BETA) ver. 0.9.9. available at http://www.cladistics.com/about_winc.html.

OCHYRA, R., J. ŻARNOWIEC \& H. BEDNAREK-OCHYRA 2003. Census catalogue of Polish mosses. - Polish Acad. Sci., Inst. Bot., Krakow: 372 pp.

OLSSON, S., V. BUCHBENDER, J. ENROTH, L. HEDENÄS, S. HUTTUNEN. \& D. QUANDT 2009. Phylogenetic analyses reveal high levels of polyphyly among pleurocarpous lineages as well as novel clades. - Bryologist 112(3): 447466.

PEDERSEN, N. \& L. HEDENÄS 2002. Phylogeny of the Plagiotheciaceae Based on Molecular and Morphological Evidence. - Bryologist 105(3): 310-324.

[TROITSKY, A.V., M.S. IGNATOV, V.K. BOBROVA \& I.A. MILYUTINA] ТРОИЦКИЙ, А.В., М.С. ИГНАТОВ, В.К. БОБРОВА, И.А. МИЛЮТИНА 2007. Вклад геносистематики в современное представление о филогении и системе моховидных. - [Contribution of molecular methods to the phylogeny and taxomomy of Bryophyta] Биохимия [Biochemistry] 72(12): 1690-1704.

VANDERPOORTEN, A. \& L. HEDENÄS. 2009. New combinations in the Amblystegieceae. - J. Bryol. 31: 129-132.

WETTSTEIN, F. v. 1924. Kreuzungsversuche mit multiploiden Moosrassen. - Biol. Zentralbl. 44: 145-168.

ZHAO, D.-P., X.-L. BAI, X.-D. WANG \& H.-M. JING 2006. Bryophyte Flora of Helan Mountain in China. - Arctoa 15 : 219-235.

Appendix 1. Studied specimen data and GenBank accessions numbers.

Species

Entodon seductrix

Herzogiella turfacea

Homomallium incurvatum

Homomallium connexum

Hookeria lucens (Hedw.) Sm.

Isopterygiopsis muelleriana

(Schimp.) Z. Iwats. 2

Mittenothamnium reptans

Ochyraea tatrensis Váňa

\section{A. Newly obtained sequences}

Specimen

U.S.A., New Jersey, Tan \#92-129 (MHA)

GenBank assession

Russia, Kunashir, Ignatov \#06-1262 (MW)

JN896314

JN896315

JQ247725

JN896316

JN896317

Russia, Primorsky Territory, Ignatov \#07-572 (MHA)

U.S.A., California, Ignatov 89-1 (MHA)

JN896318

JN896320

Honduras, Allen \# 12298 (MHA)

Czechoslovakia, coll. Váňa s. n. 30.VIII.1987 (MHA)

JQ247724 
Podperaea baii Xilin Gol 1 (gametophyte)

Podperaea baii Xilin Gol 2 (clone 1 from gametophyte) Podperaea baii Xilin Gol 3 (sporophyte)

Podperaea baii Hohhot

Podperaea baii Manhan

Podperaea krylovii Altai

Podperaea krylovii Khingan

Podperaea krylovii Primorsky 1

Podperaea krylovii Primorsky 2 Stereodon fauriei
China, Inner Mongolia,

Xilin Gol, Bai X.-L. 058141 (HIMC, MHA)

JN896321

China, Inner Mongolia,

Xilin Gol, Bai X.-L. 058141 (HIMC, MHA)

JN896322

China, Inner Mongolia,

Xilin Gol, Bai X.-L. 058141 (HIMC, MHA)

China, Inner Mongolia, Hohhot

Kou Jin \#110(7) (HIMC, MHA)

JN896323

JN896324

China, Inner Mongolia, Manhan Shan

Ignatov \#11-1 (MHA)

JN896325

Russia, Altai, Ignatov \#1/10 (MHA)

JN896326

China, Inner Mongolia,

Great Khingan Mt., Bai Xue-liang 04095 (MHA)

JN896327

Russian Far East, Primorsky Territory

Ignatov \#08-308 (MHA)

JN896328

Russia, Primorsky Territory, Ignatov \#07-220 (MHA)

JN896329

Russia, Khabarosk Territory, Ignatov, \#97-216 (MHA)

JN896313

\section{B. Previous sequences used in the present analysis}

ITS from previous studies (specimen data in Ignatov et al., 2007 or else); if ITS1 and ITS2 have different accessions they are given with / ; the only accesions means both ITS1\&2, unless otherwise is specially marked.

Breidleria pratense (J. Koch ex Spruce) Loeske AY693659; Calliergonella cuspidata (Hedw.) Loeske AF168145;Campylidium sommerfeltii (Myr.) Ochyra AY693654; Campylium stellatum (Hedw.) C. Jens. AF168151; Campylophyllum halleri (Sw. ex Hedw.) M. Fleisch. (1) AF168134; Campylophyllum halleri (Sw. ex Hedw.) M. Fleisch(2) AY693655; Caribaeohypnum polypterum (Mitt.) Ando \& Higuchi AY009799; Ctenidium molluscum (Hedw.) Mitt. AF230989 / AF403632; Drepanium (Hypnum) recurvatum (Lindb. \& Arnell) G. Roth AY693660; Entodontopsis leucostega (Brid.) W. R. Buck \& R. R. Ireland AY999175; Eurohypnum leptothallum (Müll. Hal.) Ando AY695733 / AY695786; Fabronia ciliaris (Brid.) Brid. AY528883; Glossadelphus ogatae Broth. \& Yas. AY999169; Herzogiella seligeri (Brid.) Z. Iwats. AY999174; Heterocladium dimorphum (Brid.) Bruch \& al. AY695757 / AY695771; Hygrohypnella ochracea (Wils.) Ignatov \& Ignatova AF168138; Hygrohypnella polaris (Lindb.) Ignatov \& Ignatova AY695735; Hylocomium splendens (Hedw.) Bruch et al. AJ288336 / AJ270021; Hypnum cupressiforme Hedw. AY528888 / AF403607; Isopterygiopsis muelleriana (Schimp.) Z. Iwats. 1 AY528882; Isopterygiopsis pulchella (Hedw.) Z. Iwats. AY695751 / AY695770; Leptodictyum riparium (Hedw.) Warnst. AF168163; Leptopterigynandrum austro-alpinum Müll. Hal. (1) AY693656; Leptopterigynandrum austro-alpinum Müll. Hal. (2) AF516163 / AF516158; Lescuraea secunda Arnell AF516164 / AF516150; Myrinia pulvinata (Wahlenb.) Schimp. AY528886 / AY528887; Myrinia rotundifolia (Arnell) Broth. AY528898; Myurella sibirica AJ288415 / AJ277227; Neckera pennata Hedw. AY009809; Ochyraea norvegica (Bruch \& al.) Ignatov \& Ignatova AY695753 / AY695789; Ochyraea mollis (Hedw.) Ignatov AY999178; Plagiothecium denticulatum (Hedw.) Bruch \& al. AY528892 / AY528893; Platydictya jungermannioides (Brid.) H. A. Crum AF168162; Pylaisia polyantha (Hedw.) Schimp. AY528881; Rhytidiopsis robusta (Hook.) Broth. AJ288331 / AJ288545; Sanionia uncinata (Hedw.) Loeske AF168148; Scorpidium scorpioides (Hedw.) Limpr. AY009790; Scorpidium cossonii AY625996; Struckia argentata Yunnan DQ836734; Struckia argentata Nepal Q836733; Struckia enervis Sichuan DQ836736 / DQ836737; Struckia enervis Altai DQ836735; Stereodon (Hypnum) vaucheri (Lesq.) Lindb. ex Broth. AY695762 / AY695791; Stereophyllum radiculosum (Hook.) Mitt. AY999176; Taxiphyllum wissgrillii (Garov.) Wijk \& Marg. AY999168; Tomentypnum falcifolium (Renauld ex Nichols) Tuom. AF168136; Tomentypnum nitens (Hedw.) Loeske AF168161. 